\title{
DEVELOPMENT OF A REGIONAL FOCAL POINT FOR ANIMAL GENETIC RESOURCES: THE EUROPEAN EXAMPLE
}

\author{
D. Planchenault and L. Ollivier
}

\begin{abstract}
Summary
This paper describes the process that lead to the creation of the European Regional Focal Point (ERFP). The action was suggested by FAO Global Strategy (1995) aimed to assist countries to stop animal diversity erosion by helping them with a better use and preservation of their livestock resources.

In 1997, France accepted the responsibility of developing an ERFP though its Bureau des Ressources Genetiques (BRG). During the first year, the ERFP held meaningful discussions with the different European countries with the objective of finding a general agreement for an organisational structure as well as a medium-term work programme. The following step was settled during the Annual Meeting of the European Association for Animal Production (EAAP) in Warsaw where it was agreed that the new body had to have a light structure and respect national sovereignty regarding the AnGR.

In February 2000, following a difficult internal debate involving the establishment of a basic strategy and further steps, an enquiry was launched among the National Coordinators in order to have an overall picture and to evaluate the usefulness of the proposed organisation to be established. In 2000 during the $6^{\text {th }}$ Workshop of the European NCs. The ERFP was created.

The new structure is based on:

a) an Annual Meeting of National Focal Points;

b) a Steering Committee; and

c) a Secretariat to be elected among the National Focal Points to serve for a limited period.

Keywords: Global Strategy, Conservation, Europe
\end{abstract}

\section{Introduction}

Since 1995, the FAO Global Strategy was developed to assist countries to halt erosion of animal diversity by helping the countries to use better and preserve their priceless resources. The setting up of the components of the Global Strategy is in hand. It remains still perfectly flexible.

D. Planchenault, Brg 16, rue Claude Bernard, 75231 Paris Cedex 05, France.

L. Ollivier, SGQA - INRA 78352 Jouy en Josas Cedex, France.

Paper presented at the joint RBI/EAAP International Symposium on "Conservation, management and use of rare livestock genetic resources", held in Budapest on $23^{\text {rd }}$ August 2001, printed at AGRI 2002, 32: 13-17. 
Strategy is designed to be comprehensive to emphasize the balance approach recluired to cost-effectively better understand, utilise and maintain animal genetic resources over time.

The Global Strategy's four fundamental components are:

a. An intergovernmental mechanism involving the direct countries participation through centres and networks to assist countries design, implement and maintain comprehensive strategies for the management of their animal genetic resources. The need has been clearly demonstrated to distribute the focal points to at least three levels country, regional and global.

b. A technical program of activity aimed at supporting effectives management action at the country level, in harmony with the Convention on, Biological Diversity (CBD). It includes a set of six elements:

- characterization, encompassing demographic and environmental factors, phenotypic and genetic indicators and assessment;

- in-situ utilization and conservation

- ex-situ conservation

- communication and information system development, including the development of Domestic Animal Diversity Information System (DAD-IS) and training;

- guidelines development and action planning;

- collaboration, coordination and policy instrument development.

c. Cadres of experts to guide development of the Strategy and maximize its cost-effectiveness.

d. An intergovernmental mechanism for direct government involvement, policy development and support and to maintain a national strategy adapted of the management of its own resources. This is provided by the Commission on Genetic Resources for Food and Agriculture (CGRFA).

For the implementation of the Global Strategy for Europe, FAO has closely collaborated with the EAAP (European Association for Animal Production). Created since a long time by EAAP, the existing networks were 
used by FAO. The relational aspects between the researchers, the various national and international organizations and all the animal genetic resources management actors were implied. In the field of the exchanges, many aspects were also implied mainly in the data processing from various countries. Collaboration between FAO and EAAP has been remarkable. It constitutes a fundamental difference between the Global Strategy set up in Europe and those carried out in other parts of the world.

\section{History}

In 1995, 37 European countries have responded to an invitation by FAO, nominated an institution as National Focal Point (NFP) and identified a national technical coordinator (NC). The $\mathrm{NC}$ serves as the point of contact for the country's involvement in the Global Strategy and will assist in organising the essential in-country networking, facilitating and coordinating activity. This aspect is regarded as essential for a good coordination of the national activities. To ensure the country level has access to the necessary level of assistance and to best utilise the limited resources of the Global Focus, the planned coordination structure provides for decentralisation to the region level - Regional Focal Point (RFP) - is being implemented in each major genetic storehouse region of the world.

In 1997, France has kindly agreed to accept the responsibility of developing a Regional Focal Point for Europe through its Bureau des Ressources Genetiques (BRG). This would initially occur on an interim basis and for a period of one renewable year. During this period the RFP-Europe would have in depth discussions with the different European countries with the objectives to come to a consensus for an organisational structure together with medium-term work programme. The financial implications for an operational RFP-Europe as for the other technical activities were to he clearly identified and some proposals for the funding were to be made. In this work, the BRG received the strong assistance from the NFP of Poland which was a true relay for the various exchanges between the Eastern European countries.

In 1998, in order to continue this set-up, a strong option was taken during the Warsaw meeting. First, only one RFP for Europe must be able to meet the various countries needs, but this solution must take care not to stop during the following evolutions. This RFP should have a light organisational structure taking into account the relatively weak means, which could be devoted by majority of the countries. During this first period, which could last 3 or 4 years, wisely, the majority of the countries did not want to give to the RFP a fundamental role in the decision-making processes. In the field of the farm 
animals genetic resources management, the decisions aiming at the conservation or the use of these resources must a national responsibility. However, this solution does not exclude a strong need for an international cooperation at the political and technical level.

Keeping in mind, these two basic considerations:

- set up a light structure in order to support important and future evolution,

- respect of national sovereignty in the farm animals genetic resources management and the free adhesion of the countries at this co-ordinating structure.

It should be possible to create a RFP ensuring a platform to exchange experiments and information in the field of the farm animals genetic resources management. Having a regard for the national differences, it is necessary, for economic reasons, this RFP can provide technical councils or supports in common fields. All countries should participate in these exchanges where totality of the actors who act at the local level, regional or international and from governmental or non-governmental organizations, is requested.

France was asked to continue to act as the temporary RFP Europe for one more year. During the 5th workshop for the European National Co-ordinators (NCs) for the management of Farm Animal Genetic Resources (FAnGR) in Zurich (1999), an agreement could not be made between the different European countries to allow the European Regional Focal Point (ERFP) creation. However, a new step was reached: the European countries recognized that it was not possible to establish an ERFP by a time-limited project. No formal or informal structure could continue the required work at European level. France did not have any mandate to act as the temporary ERFP.

However, it was difficult to conclude with a failure far this Zurich Workshop and the end of the ERFP set up to stimulate exchanges and dialogue between countries in the field of Farm Animal Genetic Resources (FAnGR). That is why, a small group of countries under the sponsorship of EAAP and FAO wished to carry on this work. They asked the French national coordinator to organize a vote among a11 the NCs in order to have an overall picture and to evaluate the usefulness of the proposed organisation with sufficient precision.

During this new process, the first objective was to set a voting to know the countries position concerning the ERFP creation. The first circular was sent an September 27, 1999. It proposed vote on an "idea" or on a starting point far next fruitful discussions. 
There were four main points in this proposal:

- General objectives of a European Co-ordination and benefits to be expected.

- Co-ordination ensured by one NC, based an a light structure.

- Funding provided by a dedicated trust fund financially managed and fully edited by EAAP (Rome).

- The French NFP offers to take this co-ordination in charge for a period of 4 years renewable - under the control of the annual NCs workshop.

The results were published in February 2000.:

- Thirty-seven contacted countries.

- Twenty-three answers.

- One country was against this proposal.

- One countries require more time for governmental discussions.

- One country accepts partially.

- Nineteen countries accepted this proposal.

In addition, four countries (U.K., Switzerland, Italy, France) were ready to finance a part of ERFP actions if ten countries joined this international will for collaborating.

In 2000, during the 6th Workshop for the European NCs, the ERFP was created. After three years discussions, it appeared that a light organisational structure and a simple and country driven functional structure could ensure the sustainability of a ERFP.

\section{Terms of Reference for the ERFP}

ERFP is to be established in the framework of FAO's Global Strategy on Animal Genetic Resources to serve the following needs:

- To assist and enhance the AnGR activities of National Focal Points (NFPs) at the European level and to assist in co-ordinating those activities within and between other European organisations such as the EU and the CEE.

- To develop and maintain regular contact and exchange of relevant information on AnGR horizontally among European NFPs and 
vertically with the Global Focal Point in Rame within FAO's agreed global structure.

- To stimulate the funding and organisation of regional projects, workshops and national programmes on AnGR within the European Region.

- To stimulate and co-ordinate the maintenance and further development of national databases within the European Region and encourage European information networking on AnGR.

Its structure is based on:

1) Annual Meeting of National Focal Points

- to bring together all NCs of FAO's European Region annually and normally chaired by the host country;

- to exchange information on relevant national and sub-regional activities;

- to decide on the ERFP budget, the general rules of the annual meeting, ERFP Steering Committee and Secretariat and the future activities of the ERFP;

- to elect the Secretariat NFP and the Steering Committee;

- to be advised by technical (e.g. EAAP) political (e.g. EU Commission) and organisational (e.g. FAO Global Focal Point) experts as appropriate.

2) Steering Committee

- to consist of members elected from among the NCs (initially 5 members including representatives of each of the European subregions). The preliminary Steering Committee will consist of the NCs of France Greece, the Netherlands, Poland and the UK (Chair) far one year from August 2000;

- to plan or execute activities of the ERFP as decided. upon by the Annual Meeting of NFPs;

- to represent the ERFP in contact with other institutions under the mandate of the Annual Meeting;

- to ensure that decisions with financial implications are not taken against the majority of countries that regularly fund the ERFP. 


\section{3) Secretariat}

- to be elected from among the NFPs to serve for a limited period. France has agreed to serve for the first 4 years;

- to be headed by an executive officer of the elected NFP (usually the $\mathrm{NC}$;

- to organise the Annual Meeting of the NFPs;

- to give secretarial support to the Steering Committee of time ERFP;

- to execute decisions or support projects decided in by the Annual Meeting or Steering Committee:

- to distribute relevant information on AnGR to and from NFPs and pass on information from within the FAO global network using newsletters/email/internet homepage etc.

The ERFP is funded through financial contributions made by donor countries placed in a Trust Fund administered by the Steering Committee through the Secretariat but held by and fully audited by the European Association of Animal Production (EAAP) . These funds cover basic additional costs of the Secretariat (time, communications, travel) when engaged on ERFP business, the Steering Committee and any costs for specific activities approved by the Annual Meeting.

Donors for specific programmes or projects co-ordinated by the ERFP may also make voluntary additional financial contributions.

The hosting country of the ERFP Secretariat will be expected to cover the overhead costs of office accommodation, administrative and clerical staff and communications equipment.

For the ERFP to be created, at least 10 donor European Countries must contribute to the Trust Fund a maximum of Euro 10,000 per annum each for the first 4 years to meet the budget costs.

\section{Conclusion}

The ERFP is now operational. To date, 10 countries decided to support the ERFP (Czech Republic, France, Germany, Greece, Ireland, Italy, Netherlands, Spain, Switzerland, United Kingdom). Now, many countries are convinced that the ERFP is important for the reliable management of AnGR in Europe. Important problems start to come up. With the ERFP, the countries can be better armed for them. 


\section{RAZVOJ REGIONALNE SREDIŠNJICE ZA ŽIVOTINJSKE GENETSKE RESURSE: EUROPSKI PRIMJER}

\section{Sažetak}

$\mathrm{U}$ radu se opisuje proces za stvaranje Europske središnjice (ERFF). Cilj je globalne strategije FAO-a (1995.) pomoći zemljama u zaustavljanju propadanja životinjske raznolikosti te u boljem iskorištavanju i očuvanju životinjskih resursa.

Francuska je 1997. prihvatila odgovornost za razvijanje ERFF-a kroz svoj Bureau des Ressources Genetiques (BRG). U prvoj godini ERFF je održao svrhovite debate u raznim europskim zemljama s ciljem pronalaženja općeg sporazuma za organizacijsku strukturu kao i srednjoročni program rada. Na godišnjem sastanku Europskog udruženja za proizvodnju životinja (EAAP) u Varšavi, utrđen je sljedeći korak i dogovoreno da novo tijelo mora imati laganu strukturu i poštivati nacionalni suverenitet u vezi AnGr.

$U$ veljači 2000. nakon naporne interne rasprave u vezi sa stvaranjem temeljne strategije $i$ daljnjih koraka pokrenuta je anketa među nacionalnim koordinatorima kako bi se dobila opća slika i procijenila korisnost osnivanja predložene organizacije. Godine 2000. na šestoj Radionici europskog NCs-a, osnovan je ERFF.

Nova se struktura temelji na:

a) godišnjem sastanku Središnjice

b) upravljačkom komitetu

c) sekretarijatu izabranom među članovima Središnjice na određeno vrijeme 